(c) 1983. The Genetical Society of Great Britain

\title{
VIABLE LONG-ARM DEFICIENCY IN DIPLOID BARLEY
}

\author{
R. A. FINCH \\ Plant Breeding Institute, Maris Lane, Trumpington, Cambridge, U.K. \\ Received 11.xi.82
}

This paper describes a plant of barley (Hordeum vulgare L., $2 n=2 x=14$ ) which set two seeds despite heterozygous deficiency of the long arm of chromosome 6 in all root and shoot cells studied. The plant was otherwise chromosomally normal and was a monotelodisomic in the sense of Kimber and Sears (1968). The telocentric was identified as chromosome 6 short arm by its total size and the size of the satellite beyond a secondary constriction (fig. 1). Viable deficiencies are generally rare in diploids and none has hitherto been reported in diploid barley.

The present plant arose as follows. Tsuchiya's line of Shin Ebisu 16 monotelotrisomic for chromosome 4 (Singh and Tsuchiya, 1981) was pollinated by Sultan and a monotelotrisomic $F_{1}$ was pollinated by Sultan. A monotelotrisomic derived from this backcross by one or two selfed generations was pollinated by Ahokas's line P-4 of Paavo (Finch and Bennett, 1979 ) and a monotelotrisomic $F_{1}$ from this cross gave in $F_{2}$ the monotelodisomic for chromosome 6, a primary trisomic, 11 monotelotrisomics and six normal plants. No secondary constriction was seen in any extra (15th) chromosome of sibs or ancestors of the monotelodisomic.

In glasshouses at the Institute, the monotelodisomic was dwarf and many-tillered. It took four months to ear, compared with about three months in normal barley. Leaves were relatively narrow and often lacked auricle and ligule. Spikes were deformed and mainly sterile. Pales were often awned and fused to lemmas and many spikelets had much-branched rudimentary florets and no normal organs. Some florets looked normal but did not give seed when pollinated by Sultan. Two probably selfed seeds arose in untouched florets.

Some roots and spikes were fixed in Carnoy's solution for $2 \mathrm{~h}$ or more and stained by the Feulgen method. Fig. 1 shows the karyotype in a root tip pretreated for $4 \mathrm{~h}$ in saturated aqueous 1-bromonaphthalene before fixation. The length of each identifiable chromosome type (6 short arm, 6 , 7 and 5) relative to total complement length in 5 root tip metaphases where mean total complement length per cell was $93.2 \pm 2.5$ (range 88.0 104.0) $\mu \mathrm{m}$ agrees $(P>0.95)$ with expectation from a standard karyotype adjusted for deficiency of chromosome 6 long arm (table 1). No cytological instability was seen in 2 seminal roots, 3 roots taken at ten weeks after germination when the plant was near meiosis and 5 spikes at or shortly after meiosis taken at twelve to twenty-two weeks. The deficiency was seen in all root, anther and ovule somatic metaphases studied and in all meiocytes at stages where chromosomes could be counted. Meiosis was regular at all stages in pollen mother cells (pmc's), e.g., figs. 2 and 3, and in embryo sac mother cells at leptotene, pachytene, dyad stage, prophase II and metaphase II. In all of a sample of $20 \mathrm{MI}$ pmc's, 6 symmetric bivalents and 1 asymmetric 
TABLE 1

Mean lengths of chromosomes 6 (short arm), 6, 7 and 5 as percentages of total complement length in standard diploid barley (adjusted as if deficient for chromosome 6 (long arm)) and 5 root tip metaphases of the monotelodisomic

\begin{tabular}{|c|c|c|c|c|c|c|}
\hline & \multicolumn{4}{|c|}{ Chromosome } & \multirow[b]{2}{*}{$\begin{array}{c}\chi^{2} \\
\mathrm{df}=3\end{array}$} & \multirow[b]{2}{*}{$\mathbf{P}$} \\
\hline & $\begin{array}{c}6 \\
\text { short arm }\end{array}$ & 6 & 7 & 5 & & \\
\hline Standard barley* & $3 \cdot 5$ & $7 \cdot 3$ & $15 \cdot 1$ & $12 \cdot 6$ & \multirow{2}{*}{$0 \cdot 18$} & \multirow{2}{*}{$>0.95$} \\
\hline Monotelodisomic & $3 \cdot 6$ & $7 \cdot 6$ & $13 \cdot 0$ & $13 \cdot 2$ & & \\
\hline
\end{tabular}

* Measured by present author from Linde-Laursen (1978) fig. 2.

bivalent occurred, with 1 and 1-3 chiasmata in each asymmetric and symmetric bivalent, respectively. The mean chiasma frequency per pmc was $13 \cdot 30 \pm 0 \cdot 26$ (range 11-16), with 1-3 rod bivalents per cell.

In contrast with normal barley, the final tapetal mitosis was asynchronous and did not leave all cells binucleate (Bennett and Finch, 1971), but gave many mononucleate and binucleate cells. As in normal barley (Bennett et al., 1973) male and female meiosis were concurrent in most florets. Just after the tetrad stage, about 95 per cent of young pollen grains looked normal and 4.6 per cent had a micronucleus. Mature pollen fertility was not measured.

Table 2 lists 21 plant species in which viable measurable deficiencies occur. The deficiency size estimates are approximations made from data in the cited and other sources. Small deficiencies are also claimed in Paeonia officinalis (Dark, 1936) and may cause variation in satellite size in many species besides the last three in table 2. Homozygous deficiencies are usually lethal but viable deficiency homozygotes are known in Clarkia, and in localized tissues in maize (McClintock, 1941). It is difficult to estimate the frequency of viable deficiencies in nature. Small deficiencies are easily overlooked. Heteromorphic bivalents may indicate duplications, interchanges or inversions as well as deficiencies. Apparently viable deficiencies may be supported by normal tissues in chimeras (Blakeslee and Belling, 1924; McClintock, 1929; Smith, 1943; Prasad et al., 1980). Nearly all deficiencies cause loss of vigour and fertility (though in table 2, only the Zea and Secale cases were stated to be totally sierile) and adult diploids carrying them are probably truly rare in general. $A$ t least two species in table 2 may not be true diploids, viz. Pennisetum typhoides (Jauhar, 1968), and maize (Ting, 1966; Bennett, 1983). If so, only 15 diploid species in table 2 tolerate deficiencies of over 1 per cent of the diploid genome. In a species as well studied as barley, for deficiencies to be found so rarely indicates that it is truly diploid. Viable monosomy for a sex chromosome occurs in several animals (Bridges, 1916; Burgoyne, 1978) and small viable autosomal deficiencies, some homozygous, also occur (Bridges, 1921; Coleman, 1947; Breckon and Savage, 1982).

The plant described here showed some similarity to the phenotype due to the multiflorous gene, mul2 on chromosome 6 (Tsuchiya and Haus, 1971), which was not seen in its ancestors. If this was due to hemizygosity 
TABLE 2

Amount of chromatin missing (per cent of normal diploid genome) in individuals with largest viable deficiency and $2 x$ chromosome number in 21 diploid species

\begin{tabular}{|c|c|c|c|}
\hline Species & $\begin{array}{c}\text { Chromatin } \\
\text { loss }\end{array}$ & $2 x$ & Reference \\
\hline \multicolumn{4}{|l|}{ (i) monosomics } \\
\hline Hypochoeris maculata & 11.4 & 10 & Parker et al., 1982 and pers. comm. \\
\hline Nicandra physalodes & 9.5 & 20 & Darlington and Janaki-Ammal 1945 \\
\hline Petunia $F_{1}$ & $7 \cdot 0$ & 14 & Rick 1943 \\
\hline Pennisetum typhoides & $7 \cdot 0$ & 14 & Jauhar 1970 \\
\hline Datura stramonium & 6.4 & 24 & Blakeslee and Belling 1924 \\
\hline Lycopersicum esculentum & 6.4 & 24 & Khush and Rick 1966 \\
\hline Campanula persicifolia & $6 \cdot 3$ & 16 & Darlington and La Cour 1950 \\
\hline Nicotiana alata & $5 \cdot 6$ & 18 & Avery 1929 \\
\hline Zea mays & $5 \cdot 0$ & 20 & Einset 1943 \\
\hline \multicolumn{4}{|l|}{ (ii) monotelodisomics } \\
\hline Secale cereale & $2 \cdot 6$ & 14 & R.N. Jones, Aberystwyth, pers.comm. \\
\hline Hordeum vulgare & $3 \cdot 6$ & 14 & this paper \\
\hline \multicolumn{4}{|l|}{ (iii) other large deficiencies } \\
\hline Scilla autumnalis & $13 \cdot 0$ & 12 & Ainsworth et al. 1983 and pers. comm. \\
\hline Clarkia amoena & $8 \cdot 4$ & 14 & Snow 1966 \\
\hline Leontodon hispidus & 6.5 & 14 & Finch 1967 \\
\hline Lilium formosanum & $2 \cdot 8$ & 24 & Brown and Zohary 1955 \\
\hline Hyacinthus orientalis & $2 \cdot 8$ & 16 & Darlington et al. 1951 \\
\hline Crepis capillaris & $<11.6$ & 6 & Navashin 1934 \\
\hline \multicolumn{4}{|l|}{ (iv) small deficiencies } \\
\hline Allium fistulosum & 0.7 & 16 & Zen 1961 \\
\hline Crepis tectorum & 0.4 & 8 & Philp and Huskins 1931 \\
\hline Matthiola incana & $0 \cdot 2$ & 14 & Philp and Huskins 1931 \\
\hline Galtonia candidans & $0 \cdot 2$ & 16 & Nawaschin 1927 \\
\hline
\end{tabular}

of the normal (Mul2) allele, the mul2 "allele" may really be a deletion at the $M u l 2$ locus which causes full expression of the multiflorous phenotype only when homozygous. However, the chromosome 6 centromere is not mapped (Tsuchiya, 1982) and so it is unknown whether Mul2 was hemizygous in the monotelodisomic.

The seeds from the monotelodisomic were germinated and gave normal diploid seedlings.

\section{REFERENCES}

AINSWORTH, C. C., PARKER, J. S. AND HORTON, D. M. 1983. Chromosome variation and evolution in Scilla autumnalis. Kew Chromosome Conf. 2. Brandham, P. and Bennett, M. D. (eds.). George Allen and Unwin, London.

AVERY, P. 1929. Chromosome number and morphology in Nicotiana IV. The nature and effects of chromosomal irregularities in N. alata var. Grandiflora. Univ. Calif. Publs Bot., $11,265-284$.

BENNETT, M. D. 1983. The spatial distribution of chromosomes. Kew Chromosome Conf. 2. Brandham, P. and Bennett, M. D. (eds.). George Allen and Unwin, London.

BENNETT, M. D. AND FINCH, R. A. 1971. Duration of meiosis in barley. Genet. Res., 17, 209-214.

BENNETT, M. D., FINCH, R. A., SMITH, J. B. AND RAO, M. K. 1973. The time and duration of female meiosis in wheat, rye and barley. Proc. $R$. Soc. B., 183, 301-319. 
Blakeslee, A. F. AND Belling, J. 1924. Chromosomal chimeras in the Jimson Weed. Science, N.Y., 60, 19-20.

BRECKON, G. AND SAVAGE, J. R. K. 1982. Homozygous deficiency: Syrian hamsters with only 42 chromosomes. Cytogenet. Cell Genet., 33, 285-294.

BRIDGES, C. B. 1916. Non-disjunction as a proof of the chromosome theory of heredity. Genetics, 1, 1-52, 107-163.

BRIDGES, C. B. 1921. Genetical and cytological proof of non-disjunction of the fourth chromosome of Drosophila melanogaster. Proc, natn. Acad. Sci. U.S.A., 7, 186-192.

BROWN, S. W. AND ZOHARY, D. 1955. The relationship of chiasmata and crossing over in Lilium formosanum. Genetics, 40, 850-873.

BURGOYNE, P. S. 1978. The role of the sex chromosomes in mammalian germ cell differentiation. Ann. Biol. anim. Biochem. Biophys., 18, (2B) 317-325.

COLEMAN, L. C. 1947. Chromosome abnormalities in an individual of Chorthippus longicornis (Acrididae). Genetics, 32, 435-447.

DARK, S. O. S. 1936. Meiosis in diploid and tetraploid Paeonia species. J. Genet., 32, 353-372.

DARLINGTON, C. D. AND JANAKI-AMMAL, E. K. 1945. Adaptive isochromosomes in Nicandra. Ann. Bot., New. Ser., 9, 267-281.

DARLINGTON, C. D., HAIR, J. B. AND HURCOMBE, R. 1951. The history of the garden hyacinths. Heredity, 5, 233-252.

DARLINGTON, C. D. AND LA COUR, L. F. 1950. Hybridity selection in Campanula. Heredity, 4, 217-248.

EINSET, J. 1943. Chromosome length in relation to transmission frequency of maize trisomes. Genetics, 28, 349-364.

FINCH, R. A. 1967. Natural chromosome variation in Leontodon. Heredity, 22, 359-386.

FINCH, R. A. AND BENNETT, M. D. 1979. Action of triploid inducer (tri) on meiosis in barley (Hordeum vulgare L.). Heredity, 43, 87-93.

JAUHAR, P. P. 1968. Inter- and intra-genomal chromosome pairing in an interspecific hybrid and its bearing on basic chromosome number in Pennisetum. Genetica, 39, 360-370.

JAUHAR, P. P. 1970. Chromosome behaviour and fertility of the raw and evolved synthetic tetraploids of pearl millet, Pennisetum typhoides Stapf et Hubb. Genetica, 41, 407-424.

KHUSH, G. S. AND RICK, C. M. 1966. The origin, identification, and cytogenetic behaviour of tomato monosomics. Chromosoma, 18, 407-420.

KIMBER, G. AND SEARS, E. R. 1968. Nomenclature for the description of aneuploids in the Triticinae. Proc 3rd int. Wheat Genet. Symp., Canberra. Finlay, K. W. and Shepherd, K. W. (eds.), 468-473.

LINDE-LAURSEN, I. 1978. Giemsa C-banding of barley chromosomes I. Banding pattern polymorphism. Hereditas, 88, 55-64.

McCLINTOCK, B. 1929. A 2N-1 chromosomal chimaera in maize. J. Hered., 20, 218.

McCliNTOCK, B. 1941. The association of mutants with homozygous deficiencies in Zea mays. Genetics, 26, 542-571.

NAWASCHIN, S. 1927. Zellkerndimorphismus bei Galtonia candidans Des, und einigen verwandten Monokotylen. Ber. dt. bot. Ges., 45, 415-428.

NAVASHIN, M. 1934. Chromosome alterations caused by hybridization and their bearing upon certain general genetic problems. Cytologia, 5, 169-203.

PARKER, J. S., TAYLOR, S. AND AINSWORTH, C. C. 1982. The B-chromosome system of Hypochoeris maculata III. Variation in B-chromosome transmission rates. Chromosoma, $85,299-310$.

PHILP, J. AND HUSKINS, C. L. 1931. The cytology of Matthiola incana R. Br. especially in relation to the inheritance of double flowers. J. Genet., 24, 359-404.

PRASAD, R. K. K., MURTY, T. G. K. AND LAKSHMI, K. V. 1980. Sectional translocation monosomy in a plant of Pennisetum americanum (L.) Leeke. Chromosoma, 78, 365-370.

RICK, C. M. 1943. Cytogenetic consequences of X-ray treatment of pollen in Petunia. Bot. Gaz., 104, 528-540.

SINGH, R. J. AND TSUCHIYA, T. 1981. Preliminary studies on identification of telocentric chromosomes in telotrisomic barleys by Giemsa N-banding technique. Barley Genet. Newsl., 11, 71-74.

SMITH, H. H. 1943. Studies on induced heteroploids of Nicotiana. Am. J. Bot., 30, 121-130.

SNOW, R. 1964. Cytogenetic studies in Clarkia, section Primigenia. III. Cytogenetics of monosomics in Clarkia amoena. Genetica, 35, 205-235.

TING, Y. C. 1966. Duplications and meiotic behavior of the chromosomes in haploid maize (Zea mays L.). Cytologia, 31, 324-329.

TSUCHIYA, T. 1982. Linkage maps of barley, 1982. Barley Genet. Newsl., 12, 100-104. 
TSUCHIYA, T. AND HAUS, T. E. 1971. Multiflorous 2. Barley Genet. Newsl., 1, 154.

ZEN, S. 1961. Chiasma studies in structural hybrids VI. Heteromorphic bivalent and reciprocal translocation in Allium fistulosum. Cytologia, 26, 67-73. 